\title{
PROTECTION OF GEOGRAPHICAL INDICATION UNDER TRADEMARK SYSTEM: TO FIT THE SQUARE INTO THE TRIANGLE?
}

\author{
Mas Rahmah* \\ Department of Civil Law, Faculty of Law Airlangga University, Surabaya \\ Jalan Darmawangasa Dalam Selatan, Surabaya, East Java 60286
}

\begin{abstract}
This essay will analyse the main problems of protecting Geograhical Indication (GI) under trademark law. The problems includes improper definition, inclusion of craft, the treat becomes generic, the the registration conflict and its obstacles. Furthermore, this essay assumes that trademark law seems insufficient and incompatible to protect GI. Then essay advises an alternative protection under sui generis law by firstly describing legal basis for sui generis system for GI and minimum elements in sui generis law. Finally the essay conclude whether GI in Indonesia be more appropriately protected under sui generis law or not.
\end{abstract}

Keywords: geographical indication, trademark, sui generis.

\section{Intisari}

Saat ini, perlindungan Indikasi Geografis (IG) di Indonesia diatur di bawah rezim Hukum Merek yang menimbulkan beberapa problematika yuridis. Problematika yuridis antara lain definisi IG yang tidak pas, muatan substansi IG, benturan pendaftaran IG dan Merek serta kendala lainnya. Berdasarkan kendalakendala tersebut, makalah ini mensintesakan bahwa perlindungan IG di dalam undang-undang Merek sepertinya tidak tepat sehingga perlu dikeluarkan dari undang-undang Merek. Selanjutnya makalah ini menganalisa alternatif perlindungan IG secara sui generis system sebagai pilihan yang lebih baik, dengan terlebih dahulu memaparkan landasaan hukum sui generis system dan unsur-unsur minimal yang harus ada pada sui generis system.

Kata Kunci: indikasi geografis, merek, sui generis.

\section{Pokok Muatan}

A. Introduction 537

B. Discussion 538

1. Inadequate GI Protection under Trademark Regime 538

2. Alternative Protection under Sui Generis Law 545

C. Conclusion 550

\footnotetext{
Correspondence address: rahmah.arifin@gmail.com,rahmah_arifin@yahoo.com
} 


\section{A. Introduction}

As Indonesia consists of 17.508 islands and more than 500 ethnic $^{1}$, various unique products linked to geographical factors, with high quality and wellknown reputation are found. ${ }^{2}$ These include Toraja Coffee, Gayo Coffee, Java Cocoa, Deli Tobacco, Bali Vanilla, Muntok White Pepper, Ternate Clove, Banda Nutmeg, and Jogja/Solo Batik. ${ }^{3}$ These products are highly localized with strong specificity and therefore can ber protected under Geographical Indication (GI). GI has been protected internationally under Article 22-24 TRIPS which defines GI as indications which identify a good as originating in the territory of a Member, or a region or locality in that territory, where a given quality, reputation or other characteristic of the good is essentially attributable to its geographical origin. ${ }^{4}$

In order to comply with Article 22-24 TRIPS ${ }^{5}$, Indonesia protects GI under the Trademark Law No. $15 / 2001^{6}$ (Article 56-60) which is then further regulated in Government Regulation No.51/2007 on Geographical Indication. ${ }^{7}$ However, the existing Indonesia Trademark Law (ITL) is inadequate enough to protect GI because of limited cover of protection. Therefore, sui generis law seems a necessary alternative to provide more adequate GI protection.

This essay will outline the general protection of GI in Indonesia, it includes the analysis of the existing legal framework to protect GI and the main problems of protecting GI under trademark law. Then, it analyses that trademark law seems insufficient to protect GI. It also analyses an alternative protection under sui generic law before concluding whether GI in Indonesia would be more appropriately protected under sui generis law.

The effective and appropriate legal framework for GI may solve the main problems of GI in Indonesia. Several GI problems arise in Trademark law and Trademark law seems inadequate and incompatible for GI protection, as well as cannot solve the existing GI problems. Therefore, the proposed sui generis law may the best solution because it can accommodate the basic elements of GI protection and cover the Indonesian national interest, and it may solve the main problems of GI protection under trademark law and gives the greater benefits.

The need of adequate GI protection under sui generis is important to against 'theft' of famous Indonesia GI images such as Toraja, Gayo, Java, etc. For examples, in Japan, Toraja have been registered by Japan's Key Coffee as trademark for coffee (Toarco Toraja) ${ }^{8}$ and registered for seafood snacks trademark (Torayaki Toraja). ${ }^{9}$ Whereas in Netherlands, 'Gayo' registered as a trademark by Holland Coffee B.V. ${ }^{10}$ Another case occured when the creator of Java software who is a fan of Java coffee inspired to use the name Java for his software products. ${ }^{11}$ However, Indonesia couldn't protest and took any legal actions against those registrations occured in 2001-2006 ${ }^{12}$ because Indonesia has

Surip Mawardi, Haryono, "The Importance of Geographical Indication Protection on Specific Location Product in Indonesia", Paper, workshop of the Protection of Geographical Indication for Specific Reputable Geographical Products, Denpasar, 12-13 December 2006 , p. 2. Ibid.

Marie Viven and Audry Aubard, "The GIs Implementation in ASEAN Countries", Paper, National Seminar on the Protection of Geographical Indications in Indonesia, Batam, Indonesia, 6-10 December 2004.

Article 22.1 Trade Related Aspect of Intellectual Property Right -TRIPS.

By enacting the Law No. 7 of 1994, Indonesia has ratified Agreement Establishing World Trade and its attachments such as Trade Related Aspects of Intellectual Property Right (TRIPs), therefore Indonesia has to implement TRIPS obligation including to protect GI in national law. Trademark Law No. 15 of 2001 on Indonesian Trademark Law (hereinafter ITL) was enacted on 1 August 2001.

Government Regulation No. 51 of 2007 on Geographical Indications was issued on 4 September 2007.

Surip Mawardi, "Geographical Indication Application in Indonesia: Opportunities and Challenges", Paper, Seminar on Geographical Indications: A Land of Opportunities, Hanoi, Vietnam, 15-16 November 2005, p. 3.

Directorate General of Cooperation and International Trade, "The Enhancement of the Value of Indonesian Comodities with Improvement of Geographical Indication (translation from: Peningkatan Nilai Tambah Komoditas Indonesia Dengan Pengembangan Indikasi Geografis)", http://Ditjenkpi.Depdag.Go.Id/Index.Php?Module=News_Detail\&News_Category_Id=2\&News_Sub_Category_Id=0\&News_Content_ Id=409\&Alldate=True, accessed on 14 May 2015. See also Denise Miranda, "Indonesia GI Protection", http://www.hg.org/article. asp?id=5041, accessed on 14 May 2015.

10 The Jakarta Post, "Dutch Company Claims International Trade Rights Over Gayo Coffee", 11 February 2008.

11 Directorate General of Cooperation and International Trade, Loc.cit.

12 The Jakarta Post, Loc.cit. 
not registered the names of "Toraja, Gayo and Java" neither as GI or trademark. It is important for Indonesia to complain the Gayo and Toraja trademark registrations by foreigners because those registrations prevent Indonesia to register the same name or to sell/export GI products using the name of "Toraja, Gayo or Java" abroad. The protest is also important in order to protect the Indonesian GI reputation because if the Japanese or Holland company markets their inferior quality products, consumers assume that the inferior quality products are from or has connection with Indonesian Gayo or Toraja products (coffee), then this will harm the reputation of Gayo or Toraja coffee as Indonesian GI products.

Therefore although GI protection system is a new experience for Indonesia, it is important for Indonesia government to protect GI properly because of the current trademark failure to prevent it.

\section{B. Discussion}

\section{Inadequate GI Protection under Trade-} mark Regime

\section{a. Insufficient Content of Protection and Improper Definition}

Article 22 TRIPs requires 'legal means' for protecting GI. However, TRIPS does not specify the legal means and leaves the TRIPS members to decide the form of protection. ${ }^{13}$ Therefore, GI implementation occurs in the most diverse and uncoordinated manner. ${ }^{14}$ There are three models of GI protection: (a) laws focusing on business practices such as unfair competition, or misleading of consumers passing off; (b) under trademark law; (c) special protection such as collective, certification, guarantee marks and prior recognition requirement, Protected Geographical Indication (PDI) or a Protected Designation of Origin (PDO) applied in European community. ${ }^{15}$

Indonesia regulates GI protection under trademark law in four articles only (Article 56 to 60) that the contents cannot cover broader and sufficient elements of protection. Moreover, the GI definition seems improper because Article 56(1) ITL defines that GI as:

a sign which indicates the place of origin of goods, which due to its geographical environment factors, including the factor of the nature, the people or the combination of the two factors, gives a specific characteristics and quality on the goods produced there in. ${ }^{16}$

This provision has tried to comply with the Article 22 TRIPS:

Geographical indications are, for the purposes of this Agreement, indications which identify a good as originating in the territory of a Member, or a region or locality in that territory, where a given quality, reputation or other characteristic of the good is essentially attributable to its geographical origin.

Although trying to comply with TRIPS, Indonesia GI definition is more limited than TRIPS because it covers "sign", while TRIPS uses "indication". Indonesia should include 'indication' because an indication is more subtle and broader than a sign. An indication may be a suggestion as well as a sign whereas the definition of a sign suggests a more direct connection between the sign

3 Michael Blakeney, “Geographical Indication and TRIPs", in Meir Perez Pugatch (Ed.), 2006, The Intellectual Property Debate, Perspective from Law, Economic and Political Economy, Edward Elgar, Cheltenham, p. 293.

14 J. Watal, 2001, Intellectual Property in the WTO and Developing Countries, The Sweet \& Marvel, Hague, p. 264.

15 Michael Blakeney, Ibid., p. 300. See also Phil Evan, "Geographical Indication, Trade and the Functioning of Markets", in Meir Perez Pugatch (Ed.), 2006, The Intellectual Property Debate, Perspective from Law, Economic and Political Economy, Edward Elgar, Cheltenham, UK, p. 347.

16 Unofficial translation, see also Yasmon Rangkayo Sati, 2003, Laws on the Republic of Indonesia on Intellectual Property Right, ShortCUT Gagas Imaji, Jakarta, pp. 117-118.

17 Mark Davidson, “Geographical Indication”, Unpublished Paper, 2007, p. 3. 
and the information conveyed by the sign. ${ }^{17}$ According to Mark Davidson:

An indication is not restricted to words and could include anything may identify a particular good as originating in the relevant territory, region or locality. The indication must refer to the geographical area and a straightforward interpretation of this aspect of the definition would simply reject any indication did not do so. For example, Champagne" clearly identifies a good as originating in a particular geographic area by using the name of the area. ${ }^{18}$

In addition, differ from TRIPS, GI definition in Article 56 ITL covers all of GI products, not only products having characteristic because of the natural but also human factor and the combination of both.In the additional explanation of Article 56 ITL, the scope of GI products expands including human creation such as handcrafts. Indonesia This inclusion of human factors seems similar to Article 2 (1) the Lisbon Agreement for the Protection of Appellations of Origin:

The geographical name of country, region or locality, which serves to designate a product originating therein the characteristic qualities of which are due exclusively or essentially to geographical environment, including natural and human factor.

This scope will overlap with the Indonesian copyright which protects traditional handcraft as traditional copyright that belongs to state. ${ }^{19}$ Inclusion of handcrafts exceeds the content of TRIPS'GI definition because TRIPS covers the commodity having specific characteristics because of the natural factor only, not the human factor ${ }^{20}$ thus exclude handcraft as human creations. However, some argue that GI applies for any items whether natural, agricultural, agri-industrial, manufactured or human made, ${ }^{21}$ while some argue that the scope GI scope should exclude cultural products, tradition and handicrafts employed by human, even these products relates to the culture of geographical area. ${ }^{22}$

Furthermore, the meaning of "indicates the place of origin of goods" in the article 56(1) ITL seems narrow because it covers geographic name only. The place of origin refers to geographic name, thus cannot cover non geographic names traditionally associated with a particular geographic region. This definition cannot protect, the word of "Feta" which from the Italian word but then the centuries long use of the word for a type of Greek cheese makes the name "Feta" relevant Greek territories. This cannot also cover Basmati which may associate a particular rice with parts of India although it may not establish the identity of the rice as being from particular parts of India. Thus, it is important to extend the GI definition not for geographical names only because GI is not only necessarily applicable just to direct geographic names but it is also for traditional names. ${ }^{23}$

Furthermore, definition in ITL contains unclear term of the good produced there in interpreted as the good must be mined, grown or manufactured in that territory. ${ }^{24}$ However, it is unclear on how the manufacturing process could be outsourced. For example, the wood

Article 38 of Law No. 28 of 2014 on Copyright.

Albercht Conrad, "The Protection of Geographical Indication in TRIPs Agreement", The International Trademark Association, The Trademark Reporter, January 1996, p. 5.

Bernard O’Connor, 2004, The Law of Geographical Indication, Cameron May, London, p. 53. 
used in Jepara (Central Java) furniture is not from Jepara but presumably the labour making the furniture may occur in Jepara.

In addition, the words "gives a specific characteristics and quality" may refer to some positive attribute of the goods ${ }^{25}$ that involves a subjective opinion. The term of "characteristic" may comprise attributes such as colour, texture or fragrance that may be more neutral or even unfavourable to consumers. ${ }^{26}$ In addition, TRIPs requires reputation, characteristic and quality for GI protection, whereas Article 56 ITL requires quality -which may be objectively verifiableand not a reputation because reputation may refer merely desirable characteristics. ${ }^{27}$ The exclusion of reputation will provide unfair protection because it will give the same protection effect for reputable and non reputable GI producers who had developed a reputation over years or centuries based on traditional practices or to products traditionally accepted or by slick marketing and promotion. Well known or reputable GI should obtain greater protection than nonreputable GI.

Without including reputation, the GI definition in Article 56 likely adopts the definition of appellation of origin in Article 2(1) Lisbon Agreeement: "[...] the characteristic qualities of which are due exclusively or essentially to geographical environment $[\ldots]$ ". The Lisbon Agreement requires the quality and the characteristics only and doesn't cover goods owing merely a certain reputation. On the other hands, TRIPS provides that "either the quality or the reputation or other characteristics of a certain product are attributable to its geographical origin". This means that TRIPS has a broader scope to cover products that have a certain reputation due to their geographical origin. ${ }^{28}$

\section{b. The Threat Become Generic}

Article 2 (4) Government Regulation provides that registered GI cannot be public domain or generic name although in fact it is a generic sign. This provision seems similar to Article 6 Lisbon Agreement which stipulates protected appellation of origin $^{29}$ cannot be deemed to have become generic name. Similar result comes from Article 23TRIPS, Article 4 Madrid Agreement and Article 13(3)Council Regulation No.2081/92(EC). ${ }^{30}$ However, GI may become generic in such a way that no longer serve as an indication for a specific origin of goods but become a term describing a specific kind or category of a product. ${ }^{31}$ A generic GI has therefore lost its distinctiveness and cannot principally be protected. For example the name of "French fries", "Danish pastry" and "Bermuda shorts" are generic GI. ${ }^{32}$ Champagne, Chablis, Burgundy are considered semi-generic ${ }^{33}$, while "Feta" is debatable. ${ }^{34}$

The generic GI will contrary to the trademark principle which does not protect

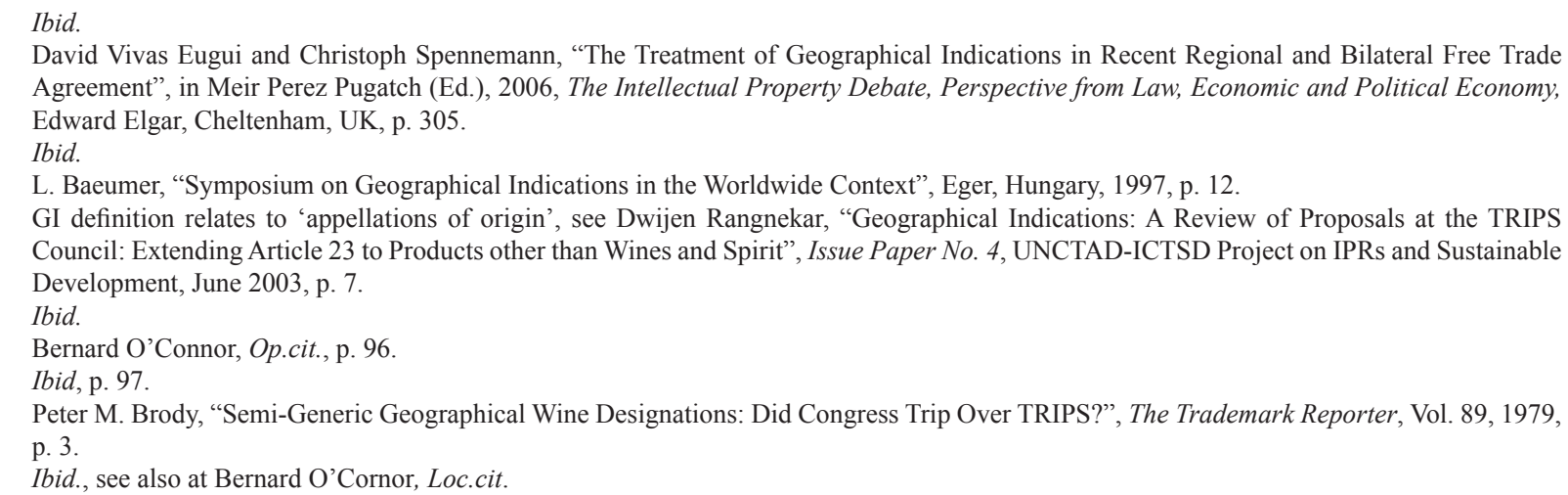


generic signs. ITL provides that generic name as part of public domain cannot be protected as trademark. ${ }^{35}$ Also, ITL does not regulate whether generic GI can be protected. Government Regulation regulates that a generic sign cannot be registered as GI. ${ }^{36}$ Generic signs refer to the signs that are to be in the public domain and hence cannot be protected. ${ }^{37}$ According to R.W. Benson, "when a product's geographic name becomes accepted as signifying the type of product, rather than its geographical source, the name is considered generic and it becomes part of public domain". ${ }^{38}$ In addition, it is difficult to determine when the GI become generic ${ }^{39}$ as the generic term may occur in different countries and in different times. ${ }^{40} \mathrm{~A}$ specific indication may be GI in the country of origin, while it may be considered as a generic name in other countries. ${ }^{41}$

\section{c. Incompatible Protection}

Some argue that GI is similar to trademark, thus, GI could be administered under the same agency, the same general statutes, and the same legal system as trademarks. Using trademark system for protecting GI has clear benefits. ${ }^{42}$ Thus, the proponents believe that trademark law is the best form for GI protection, ${ }^{43}$ whereas the opponents argue that GI protection under trademark law is not inadequate.

The GI protection under trademark law regimes is not only inadequate but also inherently unsuitable because of their different nature. GI and trademark are different legal concepts ${ }^{44}$ and therefore there is total conflict between them. WIPO recognizes the different nature between trademark and GI:

trademark is a sign used by an enterprise to distinguish its goods and services from those of other enterprises. It gives its owner the right to exclude others from using the trademark. A geographical indication tells consumers that a product is produced in a certain place and has certain characteristics that are due to that place of production. It may be used by all producers who make their products in the place designated by a geographical indication and whose products share typical qualities. ${ }^{45}$

A trademark registration system is initially hostile to GI. GI describes the geographical origin of the product rather than its trade or commercial origin, so they lack the requisite distinctiveness. ${ }^{46}$ The effort to protect GI under trademark law seems to fit "a circle of geographical indication into the square of trademark discourse".

Although the essence of trademarks and GIs is that both regulate the use of signs in the marketplace by enabling their communicative function ${ }^{47}$ and ultimately both are built on existing reputation, there are significant distinctions between them..$^{48}$

Article 5 ITL.

Explanatory of Article 3(d) Government Regulation No. 51 of 2007.

Ibid.

R.W. Benson, “Wine Briefs: The Generic Problem”, ABAJ, 1976, p. 129, see also Bernard O’Connor, Op.cit., p. 96.

WIPO, Geographical Indications and the Territoriality Principle, SCT/9/5, 11 November 2002, WIPO ${ }^{\text {th }}$ session, Geneva.

Bernard O’Connor, Loc.cit.

Ibid.

United State Delegation, 'Use of Trademark to Protect Geographical Indication', Proposed Information, 2004/ IPEG1/003, Agenda Item: 6 (1) (iii), Intellectual Property Experts' Group Meeting, Beijing, China, 20-21 April 2004, available at http://apec.org/content/apec/documents_ reports/, accessed on 25 March 2015.

Ibid.

Jeremy Philips, 2003, Trademark Law - A Practical Anatomy, Oxford University Press, London. See also Bernard O’Connor, Op.cit., p. 107. WIPO, "Geographical Indications", http://www.wipo.int/aboutip/en/geographical ind.html, accessed on 3 June 2015.

WIPO, "Summary of Replies to the Questionnaire on Trademark Law and Practice”, p. 80, WIPO Doc. SCT/14/5 Rev., 1 November 2005.

Dev Saif Gangjee, "Quibbling Siblings: Conflicts between Trademarks and Geographical Indications", Chicago-Kent Law Review, Vol. 2, 2007.

48 Stephen Stern, "Geographical Indications and Trade Marks: Conflicts and Possible Resolutions”, Paper, WIPO Symposium on Geographical Indications, San Francisco, California, 9-11 July 2004, p. 3. 
GI cannot be created by an intention to use or by the mere lodgment of an application with a registration system, whereas trademarks can do so. Trademarks are personal property, while GI is clearly a collective right of some kind, not capable of ownership by any individual but rather a fixture to the region or locality which it represents. ${ }^{49}$ A trademark must indicate the only one origin of source of goods, whereas GI can indicate many origins of goods as long as all origins emanate from the same geographical area. ${ }^{50}$ Moreover, while trademark very well might be invalidated because it has become a generic term for the product in question, registered, and protected GI cannot become generic. A trademark must be renewed every ten year, ${ }^{51}$ while a GI does not need to be renewed to gain validity as long as the specific characteristic still exist. ${ }^{52}$

Trademarks are used in order to distinguish particular goods and services from other goods. GI refers to signs used in order to distinguish products from a particular region from products coming from outside that region. Trademarks are mainly the result of human creativity, while GI is linked to something more than mere human creativity such as topography, climate, or other natural factors independent from human creativity. ${ }^{53}$ Trademarks function as the main communication between a manufacturer and the consumer to give information about the products quality, therefore a trademark puts emphasis on the producers. By contrast, GI underlines the geographical origin of a good and the characteristics derived there from. ${ }^{54}$

Trademarks can be licensed to third parties, whereas GI cannot. Therefore, controversially, some suggest that GI is not property because they cannot be bought, sold, or licensed to producers outside of the region..$^{55}$ GI is categorically not associated with private ownership but instead characterized as a right to use ${ }^{56}$. It can never be privately owned, and this is where GI differs from IP law. ${ }^{57}$ In fact, some WTO members still believe that GI are not IP ${ }^{58}$ and should not be subject to IP disciplines. Therefore, inclusion of GI in trademark law is inherently unsuitable.

\section{d. Conflict of Trademark and GI Registration}

When GI has high reputation, some parties try to register the geographical name under trademark registration or they try to obtain double protection by registering both under trademark and GI regimes. Similarity and registration under trademark and GI often lead to conflicts. Both trademarks and GI can acquire high reputation and be of commercial value and for these reasons both may be exposed to misappropriation, counterfeiting, or misuse. The following different types of problems can be identified concerning the relation between a trademark and GI: ${ }^{59}$

a. Different parties use the same sign as a trademark and as GI for the same product;

b. Similir sign is used by different

Clark W. Lackert, “Geographical Indications: What Does the WTO TRIPs Agreement Require?”, Trademark World, August 1998, p. 23.

Article 35 (1) ITL.

Article 56 (7) ITL.

Ibid.

Ibid.

Jeremy Phillips, Op.cit.

EC Response to the Checklist of Questions: Review under Art 24.2, IP/C/W/117/Add.10, 26 March 1999.

57 Louis Lorvellec, "You've Got to Fight for Your Right to Party: A Response to Professor Jim Chen", Minn. J. Global Trade 65, Vol. 69, 1996, p. 1.

58 Eleanor K. Meltzer, "Pass the Parmesan? What You Need to Know about Geograhical Indication and Trademarks", Intellectual Property Feature, June-July 2002, p. 19.

59 Lena Göransson Norrsjö, 2004, Indications of Geographical Origin as part of the Intellectual Property Law, Thesis, Stockholm Universitet, Swedia, p. 52. 
parties as a trademark and a GI for different goods, and either the trademark or the GI is wellknown

c. registered trademark, consisting of a geographical name, which is not the same as the designation of origin, has existed for a long time and become famous (not even being aware of the existence of a geographical area with the same or similar name).

In Indonesia, to avoid double registration and potential conflicts of trademark registration, Article 6(1)(c) ITL provides that:

An Application for registration of a Mark shall be refused by the Directorate General if the relevant mark has a similarity in its essential part or in its entirety with a known geographical indication. ${ }^{60}$

Article 6 ITL tries to comply with Article 23(3)TRIPS providing that:

The registration of a trademark for wines which contains or consists of a geographical indication identifying wines or for spirits which contains or consists of a geographical indication identifying spirits shall be refused or invalidated, ex officio if a Member's legislation so permits or at the request of an interested party, with respect to such wines or spirits not having this origin.

However, the prevention of conflict between GI and trademark under Article 6 (1) (c) ITL is unlikely to be useful because of the ambiguous regulation in Article 27 (2) Government Regulation that allows the good faith party to continue to use a trademark having similarity to GI if the trademark is used and registered before GI registration.
Article 22 (2) Government Regulation most likely allows uncertainty and conflict between GI and trademark to continue.

Moreover, the problem will likely emerge in registration refusal because although the DGIP has responsibility and may have the power to independently inquire into the invalidity of a trademark due to the existence of GI, it is unlikely that it would exercise that power in that manner. Collecting evidence is likely to be outside the role and beyond the resources of the DGIP. In addition, Article 6 (1) (c) ITL can also be used by any interested parties as ground being for cancellation a registered trademark that has similarity to GI. ${ }^{61}$ However, Article 68(1) ITL cannot identify the interested party who can cancel the trademark registration, can the competitors take a part? This provision can be also used by "a naughty" competitor to stop the trademark owner from using the trademark and market products. Moreover, the cancellation shall be filled within five years after the date of trademark registration. If there is no party cancel registration within the 5 (five) years, there would be no opportunity to cancel the registration of the trademark similar to GI. Consequently, it would be confusing consumers and would block the GI registration using the same name. As the first to file principle also applied to GI protection, it seems unfair that the party using GI for long periods cannot register it because it has been already registered as a trademark.

\section{e. The Obstacles of Registration Pro- cedures}

Article 56 (2) ITL provides that GI shall be protected after registration, based on the application. It is clear that the first to file principle is applied to protect GI. ${ }^{62}$

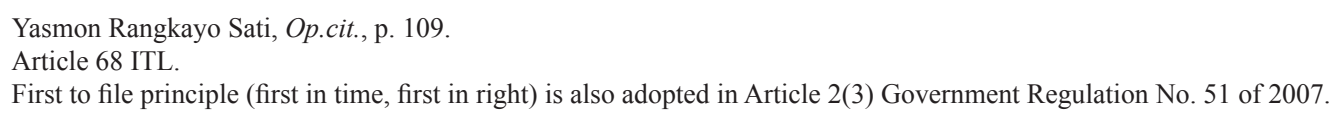


However, since then, only a small number of GI applications have been registered at DGIP because of several obstacles. Firstly, though GI is regulated under trademark law, GI registration is much more complex than trademark registration. To register GI, applicants must: (a) register the product name and GI name; (b) describe in detail the distinguishing characteristics and quality of the product and how; (c) relate to the originating location of production; (d) provide an acknowledgement of the GI products from the community of origin; and (e) describe the geographical environment, and the natural and human factors contributing to make the products, including the production process and quality testing method.

Also, an applicant must provide a book of requirements published in relation to the GI registration process. ${ }^{63}$ Creating book of requirements is also difficult because it must describe the typical and characteristics of the product distinguishing from other products, provide the description of the relationship of the geographical factor to the qualities or characteristics, and provide method description used to examine the product characteristics. As there is no database of GI identification in Indonesia, ${ }^{64}$ it is also difficult when the specification book requires a description of the history and tradition of GI including an acknowledgement from the society related to the GI use and the description of the border of the geographical area.

In addition, the GI producers must also register to use and produce GI. ${ }^{65}$ Hence, the granting of GI registration will most likely not give an automatic exclusive right to use and produce GI products. It seems an additional burden for an applicant to register twice first for GI registration and second to use and produce GI. Moreover, in relation to use and production of GI items, the parties must also comply with the stipulations in the book of requirements. Commercial uses of GI will be monitored by team of GI experts. ${ }^{66}$ GI infringements will be considered if the commercial use against the book of requirements. ${ }^{67}$ However, it is weird because the infringement is usually committed by other parties, not the GI owners themselves. IP system is a tool to protect and prevent the infringement of other parties, not the owner.

Another problem is the announcement process. Article 56(3) ITL provides that the announcement provisions for trademarks ${ }^{68}$ also apply for GI. The announcement period is three months, ${ }^{69}$ and during this period any person or legal entity can oppose the application by filing an objection. The GI applicant shall be entitled to file a rebuttal to the objection/opposition. ${ }^{70}$ However, since GI has different nature to trademark, the period of announcement should be longer than trademark as predictably, for much opposition and rebuttals regarding GI registration. In addition, there is also problem in reexamination of GI registration. It is argued that re-examination must exist if there are opposition and rebuttal. However, the Governmental Regulation provides

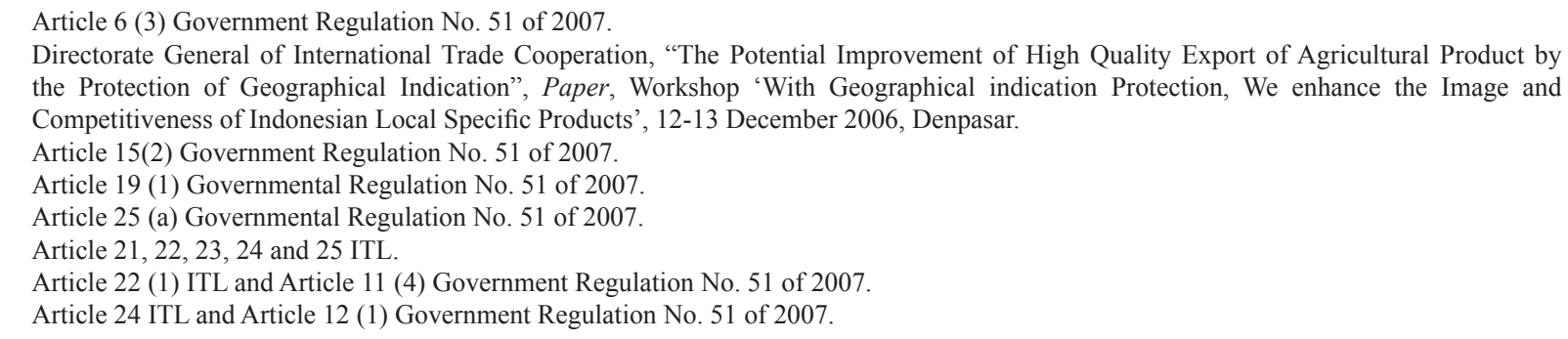


re-substantive examination ${ }^{71}$ which has a longer period (six months) ${ }^{72}$ than ITL (two months). ${ }^{73}$ The different period of re-examination indicates unparallel between ITL and government regulation.

Furthermore, Government Regulation also provides a facility for parties who have used the GI prior to its registration to continue using it for two years after its registration, as long as they acknowledge its registration and do not attempt to mislead the public about its prior use and existing registration. ${ }^{74}$ While Government Regulation also provides the same provison, the regulation does not further explain how the trademark owners should acknowledge the GI; thus, the question remains whether or not the rights of such trademark owners will be limited to enforce their rights against any use by the community that represents the GI.

\section{Alternative Protection under Sui Generis} Law

\section{a. Legal Basis for Sui Generis Law}

More and more countries around the world have established sui generis systems for GI protection. ${ }^{75}$ Since 2000, more than 12 countries from North and Latin America (such as Colombia, Venezuela, Cuba or Costa Rica) have adopted a sui generis and more than 13 (thirteen) countries in Asia (such as Mongolia, North Korea, Thailand and Vietnam) have also established sui generis protection systems for GIs in the past five years. ${ }^{76}$

TRIPS provides the legal basis for countries to develop a sui generis system that goes beyond trademark as long as it offers some sort for IP protection to GI. ${ }^{77}$ In general, countries are free to protect GI through their own legal regimes because TRIPS regulates that "members shall be free to determine the appropriate method of implementing the provisions of this agreement within their own legal system and practice". ${ }^{78}$ The spirit of this provision has always been one of latitude and discretion. ${ }^{79}$ Indeed, there is no single, talismanic method of implementing TRIPS obligations. ${ }^{80}$ Therefore, members have wide discretion over how to fulfil TRIPS obligations and could find the best ways to comply in order to meet their obligation to protect GI.

In addition, Article 22(2) $)^{81}$ TRIPs only requires applicant to provide legal means for protecting GI. TRIPs does not specify the legal means and leaves the TRIPs members to decide the form of protection. ${ }^{82}$ As long as TRIPS members have same way to effect to Article $22 \mathrm{GI},{ }^{83}$ they are free to establish any legal regime including sui generis system to protect GI. Therefore, in protecting GI, they can define and adopt sui generis system that best suits their own social and economic development, ${ }^{84}$ as well as their

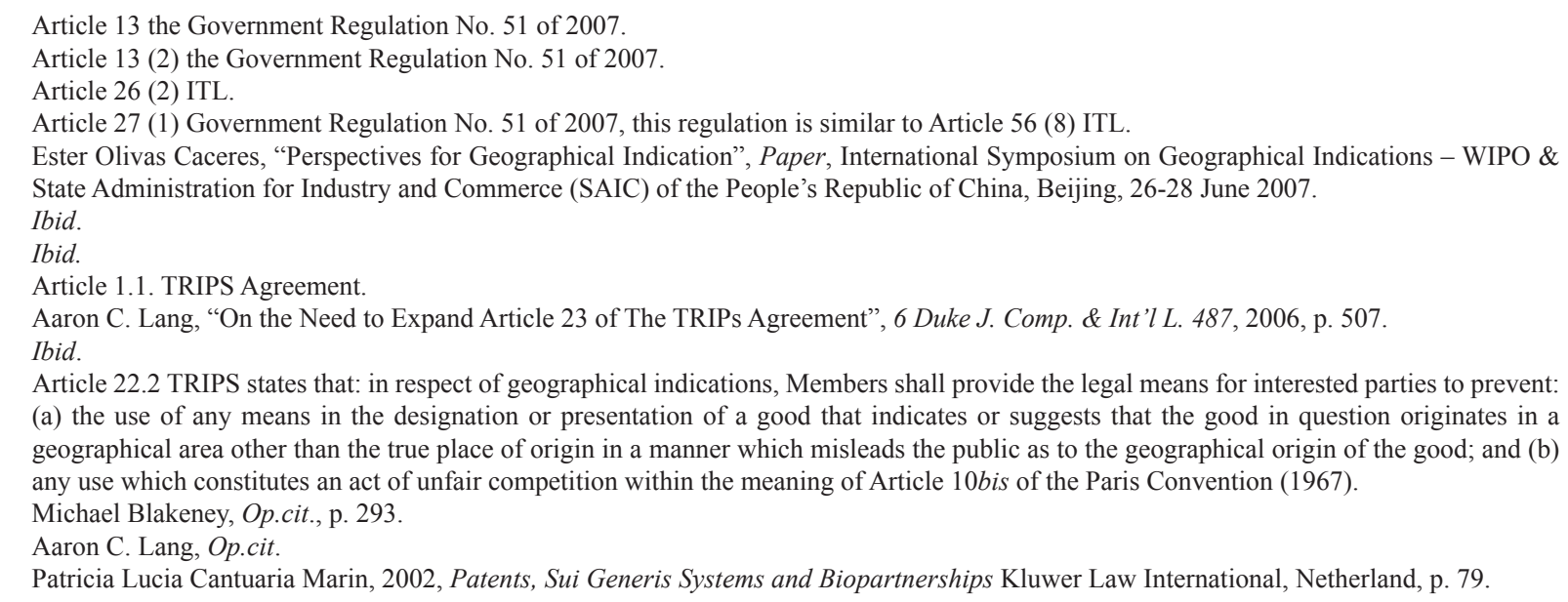


national interest. Based on Article 1(1) and Article 22 TRIPS, Indonesia can establish a sui generis system that suits national interest. By establishing sui generis system, Indonesia can address several existing GI problems under trademark.

\section{b. Minimum Elements in Sui Generis Law}

The term sui generis means 'of its own kind'. ${ }^{85}$ The Sui Generis System would have to be different from the main systems of IP protection since those are provided in other articles of TRIPS. ${ }^{86}$ As it means 'of its own kind', some argue that sui generis represents a totally new form of monopoly over GI. ${ }^{87}$ They deny the sui generis rights option proposed under TRIPS. They affirm that the sui generis right exists independently of IP ${ }^{88}$ on the basis that GI rights are inalienable and existed long before the IP regime, and they are part of national sovereignty and part of human rights. ${ }^{89}$

However, this argument is not totally right because although GI differs from trademark, GI must be treated as an IP. Therefore, GI protection under sui generis system must be compatible with TRIPS standards. It means that the standard of sui generis should provide at least: ${ }^{90}$ (a) the right covered and requirements, (b) the principle of national treatment ${ }^{91}$ and principle of most favoured nation ${ }^{92}$, (c) cover all GI products, not only wines or spirits, (d)enforcement mechanism. WIPO advises how the law defines or establishes GI: ${ }^{93}$ (a) policy objective of the GI protection, (b) subject matters and criteria, (d) ownership and rights conferred and the exceptions, (e) procedures, formalities for acquisition and maintenance of the rights conferred, (f) enforcement, ( $g$ ) effective penalty for infringement, (h) how the rights are lost or expired, (i) interaction with, overlaps or complements existing IP standards.

Sui generis law must provide the mechanism to get GI rights. Generally, GI protection is based on registration like in EU, ${ }^{94}$ although Singapore, India, and Latvia have passive or non registration protection. ${ }^{95}$ Indonesia should apply the registration system as it affords better protection and certainty. ${ }^{96}$

Furthermore, sui generis must define clearly what names can be registered. Some system only allow the direct geographical names such as in the Russia, while other systems permit inclusion of traditional names, geographical or figurative representations or any combination suggesting of GI. ${ }^{97}$ It is important to Indonesia to cover not only geographical names butalso traditional names, geographical or figurative representations or

87 The Thammasat Resolution, "Building and Strengthening Our Sui Generis Rights", Final Declaration of the meeting held by the Thai Network on Community Rights and Biodiversity (BIOTA) and Genetic Resource Action International (GRAIN), Bangkok, Thailand, 1-6 December 1997.

90 Patricia Lucia Cantuaria Marin, Op.cit., p. 69.

1 National treatment means that Each Member shall accord to the nationals of other Members treatment no less favourable than that it accords to its own nationals with regard to the protection of intellectual property, subject to the exceptions already provided [...] (Article 3(1) TRIPS).

92 Most Favoured Nation means that with regard to the protection of intellectual property, any advantage, favour, privilege or immunity granted by a Member to the nationals of any other country shall be accorded immediately and unconditionally to the nationals of all other Members (Article 4 TRIPS)

93 International Intellectual Property Institute (IIPI), “Is a Sui Generis System necessary?”, IPTF Luncheon, New York, 14 January 2004, p. 3.

94 EC Regulation 2081/92 of 4 July 1992 on the protection of geographical indications and designation of origin for agricultural products and foodstuffs, OJ L 208, 24/07/1997, as last amendment by EC Regulation 692/2003 of 8 April 2008, OJ L 99, 17/04/2003.

95 Bernard O’Connor, Op.cit., p. 74.

96 Ibid., p. 75.

97 Ibid., p. 78. 
any combination suggesting of GI in orde to provide broader scope of protection.

Sui generis may regulates the provision of generic GI. It is important to consider Article 3 of EC Regulation 2081/92 which establishes whether or not a name has become generic. ${ }^{98}$ In EC Regulation 2081/92, relevant factors to considering the generic or homonymous GI includes ${ }^{99}$ : (a) the existing situation in the EC Member State in which the name originates; (b) the situation of the area of consumption; (c) the existing situation in other states; and (d) the relevant national or community laws. For comparison, India regulates that homonymous GI can be registered only if there will be no confusion, after considering the practical conditions under which the homonymous indication in question can or would be differentiated from other homonymous indications. ${ }^{100}$

In addition, sui generis law must provide the legal basis for establishment of national GI agency with authority to coordinate GI identification ${ }^{101}$ and protect GI nationally. In addition, sui generis law must give the legal power for a team of GI experts which has authority to examine GI registrations and control GI commercial uses. To control registered GI efectively, Indonesia may adopt the system in EC Council legislation (Regulation 2081/92) ${ }^{102}$ that allow public or private body to control GI under coordinating national GI agency.

Sui generis should regulates the ownership of GI. Principally, GI is a collective ownership, therefore the GI owner should be not an individual rather than society, local government and the local producers or the farmers groups. The problem can arise if the GI product is located in the middle of the border area or the relevant region or locality may not be clearly defined, particularly where there are no clear natural or political borders such as rivers or provincial borders. ${ }^{103}$ It could then lead to potential conflict between two or more local governments to claim the GI products. Each local government would be probably entitled to be the GI owner and have authority to register GI products.

Sui generis should also solve problem between local and central government in relation to the GI agricultural and handy craft products. This potential conflict is related to the authority and the ownership problem as well. The local governments would be probably entitled to be GI owners and register GI products because GI products are located and cultivated in the local area. On the other hand, the provision in Article 7of the Law No $29 / 2000$ regulates that if the agricultural product is a traditional one, it is owned by state. ${ }^{104}$ Also for traditional handicrafts, the

98 Article 3 (1) EC Regulation 1081/92 states that: "[...] generic names or indications in relation to goods, means the name of a good which, although related to the place or the region where the goods was originally produced or manufactured, has lost its original meaning and has become the common name of such goods and serves as a designation for or indication of the kind, nature, type or other property or characteristic of the goods".

99 Article 3 of EC Regulation 2081/92.

100 Section 10 the Geographical Indication of Goods Act of India, 1999, No. 48.

101 Ibid., Indonesia has divided the GI identification tasks to national agencies: (1) DGIP, has a task to identify the regulations for GI protection; (2) Secretariate of Cabinet (Vice Presidential Secretary) and DGIP, have tasks to analyse and accommodate the required regulation for implementation of GI protection; (3) Ministry of Research and Technology and Ministry of Enviroment, have a task to identify GI product; (4) Research and Development Institution of the Department of Forestry, has tasks to identify and undertake R\&D GI agricultural products; (5) Supervision of Medicine and Food Body, has task to identify GI medicinal products; (6) Directorate General of Small and Intermediate Industry, has task to help centre of industries to develop GI products; and (7) Directorate General of Cooperation of International Trade, has task to monitor international negosiation and overseas GI registration.

102 For private body, EC Regulation 2981/92 requires that privates inspection bodies are required to be accredited to European Standard EN 45011, equivalent to the ISO Standard 65. Private bodies must also offer adequate guarantee of objectivity and impartiality with regard to all producers to their control and have permanently qualified staff and resources to carry out inspection. See Article 10 EC Regulation $2981 / 92$.

103 Albrecht Conrad, "The Protection of Geographical Indications in the TRIPS Agreement", Trademark Reporter 11, Vol. 86, 1996, p. 12. See also Geographical Indications Committee v The Honourable Justice O'Connor [2000] FCA 1877.

104 Law No. 29 of 2000 on The Protection of Plant Variety Right. 
owner is the state. ${ }^{105}$ However, the definition of state is unclear. If state is interpreted as the central government, there seems no opportunity for local governments, local society or local producers or farmers to register traditional agricultural products and handcrafts to gain GI protection.

\section{c. Sui Generis Law Seems More Appropriate}

There is an important trend of sui generis GI protection systems and this system will certainly facilitate the protection of GI effectively. Most countries recognize the need for a sui generis GI protection system. ${ }^{106}$ Several countries applying a sui generis system do not encounter major difficulties in protecting their GI. It is much more difficult for GI producers to rely on unfair competition and consumer protection acts, passing off actions or the trademark regime. ${ }^{107}$ Experience shows that securing protection in that context is a difficult, expensive and largely uncertain process. ${ }^{108}$

Since there is a fundamental, philosophical conflict between the GI protection and trademarks, trademark regime is inappropriate to protect GI. Trademark law may not be the best mechanism of securing exclusive rights to use a GI. The trademark system is often ill-equipped to provide protection geographical names that have specific characteristics that allow them to be identified as unique development tools. ${ }^{109}$

The use of a trademark regime to protect a GI name does not provide for a protection as comprehensive as the one offered by a sui generis GI system. The experience of many GI producers shows that the use of a trademark regime has proved extremely difficult, very complicated, often very costly and not always effective to protect their GIs.

Most trademark laws including Indonesian trademark law, in general, prohibit the registration of a name with a geographical meaning. Therefore, GI names are often protected via a collective or a certification mark when such legal concepts exist. When they are not available, GI producers have often been forced to seek a limited protection - for their logo only - via a figurative trademark registration. ${ }^{110}$ In the sui generis system, this problem might be solved by providing the registration of a name with a geographical meaning.

In addition, experience shows that some IP offices including the Indonesian IP office (DGIP) regularly reject geographical name registration on the grounds that GI names are a simple indication of the place of origin of the goods (i.e. an indication of source), a description of the product, and or a generic name. However, sui generis GI system of protection does not face these problems as the GI concept is in essence descriptive of a geographic origin.

Sui generis law may solve problem that in some countries including in Indonesia, GI producers are confronted with registered trademarks that contain their GI names. According to the principle of first-in-time, first-in-right applicable to trademarks, it is therefore impossible for producers to seek trademark registration of a geographical name that is already legally owned by others.

Article 38 (1) The Law No. 28 of 2014 on Copyright.

6 Ester Olivas Caceres, Loc.cit.

107 Ibid.

108 Ibid.

109 Ibid., p. 2.

110 Ibid., p. 3

11 The International Trademark Association (INTA) has suggested that this should be the solution for Trademark v. GI conflicts. See "INTA's Resolution: Protection of Geographical Indications and Trademarks (September 24, 1997)", http://www.inta.org/policy/res_geoindtms.html, accessed on 17 August 2015. 
The principle of first-in-time, first-in-rights means that in case of a conflict between two marks similar or the same, the one that has prior rights will triumph. ${ }^{111}$ If the principle of first-in-time is applied, then these applications would be able to prohibit others, including authentic GI producers, from selling their product under the same GI name. Such a situation has occurred in the past, when Italian producers of Parma ham were obstructed from initially registering their marks in both the US ${ }^{112}$ and Canada ${ }^{113}$ because of a prior registration for Parma. Indonesia also faced the problem of selling or exporting Gayo Coffee as Holland Coffee B.V. has registered the name of Gayo as trademark. ${ }^{114}$ In such a case when GI has been registered as a trademark by others, GI producers have only two options. They can launch proceedings to obtain the cancellation of the registered trademark or they can enter into negotiation with the owner of the trademark in order to buy it. In both cases, actions launched by GI producers have proved very costly and not always 100 percent successful. ${ }^{115}$

Sui generis law must address the problem that some IP can offices accept registration of a certification mark covering the composed GI name but cannot always cover the protection of the two individual terms in other countries. For instance, Indonesia cannot protest registration Toraja name for Toarco Toraja or Torayaki Toraja which are registered as trademark in Japan.

In most countries, trademarks are protected if they are registered. However, for the protection to be effective, trademarks must be used on the market. Trademark registration confers a limited protection during ten years. Proof of use or justification of non-use are required to allow the registration to remain in force. However, trademark might become generic if it is used for a long time and then it cannot be protected. By contrast, GI protection gives an indefinite protection despite the use of such product and once they are registered, they will never become generic. Therefore, sui generis system will more effectively protect GI perpetually and prevent GI becoming generic.

Use of a trademark regime to protect a GI name does not provide for a protection as comprehensive as the one offered by a sui generis system. Trademark registration does not cover translation, nor does it prevent the use of the name with "de-localisers" (i.e. "Spanish Champagne") or expressions such as "like and style". By contrast, GI protection under the sui generis system covers the name, its translation in any language and the use with expressions like "style", "type", and "make".

Although a trademark registration provides exclusive rights on the registered name, GI producers must continue to assert their rights. They need to carry out a regular monitoring of the markets where the trademark is protected. The cost of surveillance for protecting the trademark is expensive. By contrast, the cost of market surveillance of GI in sui generis systems is optional.

According to the trademark system, respect for the legal rules has to be pushed by the companies that want their name protected as well the actions for infringement of collective marks must be initiated by the individual trademark owner. For GI, under sui generis law state or local governments can push for enforcement of GI legislation 
Sui generis law is needed as it could provide the incentive for local manufacturers to enhance commerce in producing, distributing and selling those products domestically and worldwide and improve competitiveness at the global markets. Since products are mostly manufactured in a local area, appropriate GI protection may increase local employment opportunities and reduce migration and high rate of unemployment in major cities. In addition, the purpose of adequate GI protection is to prevent free riding by others using the GI reputation and to prevent misrepresentation and misleading of GI brand.

\section{Conclusion}

The GI protection under trademark law regimes is not only inadequate but also inherently unsuitable because of their different nature. Sui generis might provide the best solution for the problem of GI under trademark regime. Sui generis will be easier to protect GI perpetually and to prevent GI becoming generic. In addition sui generis systems allow for costless registration and market surveillance cost of GI in sui generis systems is optional. Moreover, under sui generis law State or local governments can push for the enforcement of GI legislation more intensively. Therefore, it can be concluded that GI protection under sui generis would be more appropriate than under trademark regime.

\section{BIBLIOGRAPHY}

\section{A. Books}

Gervais, D., 2003, The TRIPs Agreement: Drafting History and Analysis, Sweet and Maxwell, London.

Marin, Patricia Lucia Cantuaria, 2002, Patents,

Sui Generis Systems and Biopartnerships, Kluwer Law International, Netherland.

Norrsjö, Lena Göransson, 2004, Indications of Geographical Origin as part of the Intellectual Property Law, Thesis, Stockholm Universitet, Swedia.

O'Connor, Bernard, 2004, The Law of Geographical Indication, Cameron May, London,

Philips, Jeremy, 2003, Trademark Law - A Practical Anatomy, $2^{\text {nd }}$ Edition, Oxford University Press, Oxford.

Sati, Yasmon Rangkayo, 2003, Laws on the Republic of Indonesia on Intellectual Property Right, ShortCUT Gagas Imaji, Jakarta.

United Nations Conference on Trade and Development, International Centre for Trade and Sustainable Development, 2005, Resource Book on TRIPS and Development, Cambridge University Press, Cambridge.

Watal, J., 2001, Intellectual Property in the WTO and
Developing Countries, Springer Netherland, The Hague.

\section{B. Anthology}

Blakeney, Michael, "Geographical Indication and TRIPs", in Meir Perez Pugatch (Ed.), 2006, The Intellectual Property Debate, Perspective from Law, Economic and Political Economy, Cheltenham, UK.

\section{Anthology}

Eugui, David Vivas and Christoph Spennemann, "The Treatment of Geographical Indications in Recent Regional and Bilateral Free Trade Agreement”, in Meir Perez Pugatch (Ed.), 2006, The Intellectual Property Debate, Perspective from Law, Economic and Political Economy, Edward Elgar, Cheltenham, UK. Evan, Phil, "Geographical Indication, Trade and the Functioning of Markets", in Meir Perez Pugatch (Ed.), 2006, The Intellectual Property Debate, Perspective from Law, Economic and Political Economy, Cheltenham, UK.

\section{Journal Articles}


Benson, R.W., "Wine Briefs: The Generic Problem", $A B A J$, Vol. 62, 1976.

Brody, Peter M., "Semi-Generic, Geographical Wine Designations: Did Congress Trip Over Trips?, The International Trademark Association", The Trademark Reporter, Vol. 89, 1979.

Conrad, Albrecht, "The Protection of Geographical Indications in the TRIPS Agreement", Trademark Reporter, Vol. 86, January 1996.

Gangjee, Dev Saif, "Quibbling Siblings: Conflicts between Trademarks and Geographical Indications", Chicago-Kent Law Review, Vol. 82, No. 2, 2007.

Lackert, Clark W., "Geographical Indications: What Does the WTO TRIPs Agreement Require?", Trademark World, August 1998.

Lang, Aaron C., "On the Need to Expand Article 23 of The TRIPs Agreement", Duke J. Comp. \& Int'l L. 487, Vol. 6, 2006.

Lorvellec, Louis, "You've Got to Fight for Your Right to Party: A Response to Professor Jim Chen", MINN. J. GLOBAL TRADE, Vol. 5, 1996.

Meltzer, Eleanor K., "Pass the Parmesan? What You Need to Know about Geograhical Indication and Trademarks", Intellectual Property Feature, June/July 2002.

\section{E. Papers}

Baeumer, L., "Symposium on Geographical Indications in the Worldwide Context", Paper, Eger, Hungary, 1997.

Directorate General of International Trade Cooperation, "The potential improvement of High Quality Export of agricultural product by the protection of geographical Indication', Paper, Workshop of 'With Geographical Indication Protection, we enhance the image and competitiveness of Indonesian local specific products', 12-13 December 2006, Bali, Indonesia.

Caceres, Ester Olivas, "Perspectives for Geographical Indication", Paper,
International Symposium On Geographical Indications - WIPO \& State Administration for Industry and Commerce (SAIC) of the People's Republic of China, Beijing, 26-28 June 2007, WIPO/GEO/BEI/07/13, 22 June 2007.

Indonesian Delegacy, "Geographical Indication", Paper, on $\mathrm{Eu}$ - Asean Regional Workshop On Geographical Indications, Hanoi, 7-8 October 2003.

Mark Davidson, "Geographical Indication", Unpublished Paper, 2007.

Mawardi, S., J. Avelino, B. Sallee, J.J. Perriot, D. Sautier, C. Lelong, M. Jacquet, F. Ribbeyre, V. Keller, 'Developing Geographical Indication Protection in Indonesia: Bali Kintamani Arabica Coffee as a Preliminary Case', Paper, Seminar on Geographical Indication: A Land of Opportunities, Hanoi (Vietnam), 15-16 November 2005.

Stern, Stephen, "Geographical Indications and Trade Marks: Conflicts and Possible Resolutions", Paper, WIPO Symposium on Geographical Indications, San Francisco, California, July 9-11, 2004.

United State Delegation, "Use of Trademark to Protect Geographical Indication", Proposed Information, 2004/ IPEG1/003, Agenda Item: 6(1)(iii), Intellectual Property Experts' Group Meeting, Beijing, China, 20-21 April 2004.

WIPO, Geographical Indications and the Territoriality Principle, SCT/9/5, 11 November 2002, WIPO $9^{\text {th }}$ session, Geneva. , Summary of Replies to the Questionnaire on Trademark Law and Practice, at 80, WIPO Doc. SCT/14/5 Rev. (Nov. 1, 2005).

\section{F. Internet Articles}

Miranda, Denise, "Indonesia GI Protection", http:// www.hg.org/article.asp? $i d=5041$, accessed on 14 May 2015.

The International Trademark Association (INTA), “INTA's Resolution: Protection of 
Geographical Indications and Trademarks

(24 September 1997)", http://www.inta.org/ policy/res_geoindtms.html, accessed on 17 August 2015.

WIPO, "Geographical Indications", http://www. wipo.int/aboutip/ en/geographical_ind.html, accessed on 3 June 2015.

\section{G. Newspaper}

Bisnis Indonesia, "GI Substantive Examination Faces the Problem of Team of GI Experts", (translation from Pemeriksaan Indikasi Geografis Terbentur Tim Ahli), Bisnis Indonesia, 13 March 2008.

Redactor of The Jakarta Post, "Dutch company Claims International Trade Rights over Gayo Coffee", The Jakarta Post, 11 February, 2008.

\section{H. Government Regulations}

Law Number 29 of 2000 on The Protection of Plant Variety (State Gazette of the Republic of Indonesia Year 2000 Number 241, Supplement to State Gazette of the Republic of Indonesia Number 4043).
Law Number 51 of 2001 on Trademark (State Gazette of the Republic of Indonesia Year 2001 Number 110, Supplement to State Gazette of the Republic of Indonesia Number 4131).

Law Number 28 of 2014 on Copyright (State Gazette of the Republic of Indonesia Year 2014 Number 266, Supplement to State Gazette of the Republic of Indonesia Number 5599).

Government Regulation Number 51 of 2007 on Geographical Indication (State Gazette of the Republic of Indonesia Year 2007 Number 115, Supplement to State Gazette of the Republic of Indonesia Number 4763).

\section{International Agreements}

TRIPs Agreement.

Lisbon Agreement.

Madrid Agreement.

\section{J. Miscellaneous}

E.C. Response to the Checklist of Questions: Review under Art 24.2, IP/C/W/117/Add.10 (Mar. 26, 1999). 